\title{
The genomic organization and transcriptional pattern of genes encoding nitrate transporters 1 (NRT1) in cucumber
}

\author{
M. Migocka • A. Warzybok • G. Kłobus
}

Received: 3 January 2012 / Accepted: 25 June 2012 /Published online: 14 July 2012

(C) The Author(s) 2012. This article is published with open access at Springerlink.com

\begin{abstract}
Background and Aims NRT1 proteins are $\mathrm{H}^{+}$-coupling nitrate transporters which belong to the family of peptide transporters (PTRs) and facilitate low and high affinity nitrate transport systems in a model plant Arabidopsis thaliana. In this study, we present the first inventory of the Cucumis sativus NRT1 family together with the transcriptional profile of CsNRT1 genes suggesting the physiological function of the family members in cucumber.

Methods Semiquantitative RT- PCR was used to analyze the level and organ-distribution of expression of $C s N R T 1$ genes. The response of those CsNRT1s, whose transcripts were clearly detectable in vegetative tissues to different level of nitrate supply was examined through real-time PCR assays.
\end{abstract}

Responsible Editor: Ad C. Borstlap.

Electronic supplementary material The online version of this article (doi:10.1007/s11104-012-1345-x) contains

supplementary material, which is available to authorized users.

M. Migocka $(\bowtie) \cdot$ A. Warzybok $\cdot$ G. Kłobus

Institute of Experimental Biology, Department of Plant

Physiology, Wroclaw University,

Kanonia 6/8,

50-328 Wroclaw, Poland

e-mail: mmigocka@biol.uni.wroc.pl
A. Warzybok
e-mail: anka.warzybok@biol.uni.wroc.pl
G. Kłobus
e-mail: klobusg@biol.uni.wroc.pl

Results The newly identified cucumber NRT1s were given the designation according to their homology to A. thaliana AtNRT1s. The comparison of the Arabidopsis and cucumber NRT gene families, similarly to the previous comparison of NRT1s in Arabidopsis, poplar and grasses, reveals some striking differences in genes' structure and quantity.

Conclusions The putative function of particular CsNRT1 proteins is discussed, considering the results obtained here as well as the already published studies on A. thaliana NRT1 transporters.

Keywords Nitrate - Nitrate transporters NRT1, NRT2 CLC chloride channels · HATS · LATS

\section{Introduction}

Nitrate is the major source of inorganic nitrogen taken up by plants grown in aerobic soils. Its concentration fluctuates spatially and temporary, because of leaching and microbial activity. Thus, plants have evolved physiological and morphological adaptations to tackle variable availability of soil nitrate, which comprise the regulation of root architecture as well as complex regulation of network transporters involved in both nitrate uptake and its distribution within the plant.

During the past two decades a profound progress in the molecular recognition and characterization of nitrate transporters in plant cells has been observed. It has been established that nitrate uptake by plants is an 
active, $\mathrm{H}^{+}$-coupled process facilitated through the highand low-affinity transport systems (HATS and LATS) which could be constitutive or inducible (Glass and Siddiqi 1995; Glass et al. 2001, 2002; Zhao et al. 1999; Tischner 2000; Touraine and Gojon 2001; Forde 2002). Also the nitrate influx into vacuole (Blumwald and Poole 1985; Schumaker and Sze 1987; Kabała et al. 2003; de Angeli et al. 2006; von der Fecht-Bartenbach et al. 2010) as well as its efflux out of the plant cell (Segonzac et al. 2007; Lin et al. 2008) have been shown to be driven by a proton motive force. Active nitrate transport across plant cell membranes has been attributed to three families including the proton-coupled symporters and antiporters belonging to NRT1, NRT2 (Tsay et al. 2007) and CLC multigenic families (de Angeli et al. 2006, 2009; von der Fecht-Bartenbach et al. 2010). The completion of the Arabidopsis thaliana genome sequencing project revealed the presence of 53, 7 and 6 genes encoding NRT1, NRT2 and CLC transporters, respectively. Expression of some of the identified genes has been shown to be differentially influenced by nitrate, ammonia, $\mathrm{N}$ starvation and $\mathrm{N}$ metabolites, sucrose, circadian rhythm or pH (Filleur and Daniel-Vedele 1999; Lejay et al. 1999; Geelen et al. 2000; Glass et al. 2002; Okamoto et al. 2003; Gojon et al. 2009). Nitrate itself also significantly affects nitrate transporters expression and thus influences the rate of $\mathrm{NO}_{3}{ }^{-}$uptake, distribution, accumulation and efflux within plant cells and tissues.

The nitrate transporters that have been so far characterized localize to plasma membrane (NRT1s and NRT2.1) or tonoplast (CLCa, CLCb, CLCc, NRT2.7). NRT2 are inducible (NRT2.1, NRT2.2) or constitutively (NRT2.4-NRT2.6) expressed high-affinity nitrate transporters, among which only a few members have been characterized in detail: NRT2.1 and NRT2.2 were shown to be responsible for nitrate uptake from the soil whereas NRT1.7 determines $\mathrm{NO}_{3}{ }^{-}$storage in seeds (Orsel et al. 2002; Okamoto et al. 2003; Tsay et al. 2007; Wirth et al. 2007; Li et al. 2007; Chopin et al. 2007). Three tonoplast-localized members of CLC family in Arabidopsis operate as nitrate transporters: CLCa, which functions as a $2 \mathrm{NO}_{3}{ }^{-} / 1 \mathrm{H}^{+}$antiporter critical for $\mathrm{NO}_{3}{ }^{-}$accumulation within vacuoles (Geelen et al. 2000; de Angeli et al. 2006) and CLC-b as well as CLC-c, which regulate the level of vacuolar nitrate in plant cells (Harada et al. 2004; von der Fecht-Bartenbach et al. 2010).

NRT1, the third family of nitrate transporters in plants has received particular attention during the last few years. Although the Arabidopsis genome contains 53 NRT1 (PTR) genes, the function in $\mathrm{NO}_{3}{ }^{-}$transport was confirmed only for 8 NRT1s (AtNRT1.1-1.2 and AtNRT1.4-1.9). Arabidopsis NRT1.1 (CHL1) and NRT1.2 nitrate transporters were shown to be involved in nitrate uptake from the soil solution into root cells (Tsay et al. 1993; Wang et al. 1998; Huang et al. 1999; Liu et al. 1999; Orsel et al. 2006; Li et al. 2007). Root-to-shoot nitrate transport is probably governed by three members of AtNRT1 family: two closely related transporters NRT1.5 and NRT1.8, are responsible for loading or retrieving nitrate from xylem sap, respectively, whereas root stele-expressed AtNRT1.9 is involved in the loading of nitrate into the root phloem to enhance downward nitrate transport in roots (Wang and Tsay 2011). The remaining AtNRTs operate in shoots, where they are involved in nitrate storage in leaf petioles (NRT1.4), $\mathrm{NO}_{3}{ }^{-}$ translocation from maternal tissue to developing embryos (NRT1.6) or the remobilization of $\mathrm{NO}_{3}{ }^{-}$from older to younger leaves (NRT1.7) (Chiu et al. 2004; Almagro et al. 2008; Fan et al. 2009).

The molecular features of nitrate transport within plants and the regulation of this process have been thoroughly studied mostly in the model plant Arabidopsis thaliana. In contrast, until now the molecular characterization of nitrate transporters from other species, especially those important for agriculture is still lacking due to the unavailability of full genome resources. The question arises, whether nitrate transporters from other species show similar regulation, expression and function as their Arabidopsis counterparts. Since the genome of cucumber has already been completely sequenced twice (Huang et al. 2009; Wóycicki et al. 2011) and the results of sequencing projects were made available, we searched the GenBank database for cucumber homologs of the designated A. thaliana NRT1 genes. Here we present the first inventory of cucumber NRT1 genes together with detailed analyses of their expression pattern in different organs and under constant or variable nitrate supply.

\section{Material and methods}

Plant material

Seeds of cucumber plants were germinated in darkness and then grown hydroponically for 4 weeks on 
nutrient solutions, $\mathrm{pH}$ 6.0, containing $0.17 \mathrm{mM} \mathrm{Ca}$ $\left(\mathrm{H}_{2} \mathrm{PO}_{4}\right)_{2}, 1.5 \mathrm{mM} \mathrm{CaSO} 4,0.33 \mathrm{mM} \mathrm{MgSO} 4$, $25 \mu \mathrm{M}$ ferric citrate, $3 \mu \mathrm{M} \mathrm{MnSO} 4,1.7 \mu \mathrm{M} \mathrm{H}_{3} \mathrm{BO}_{3}$, $0.3 \mu \mathrm{M} \mathrm{CuSO}_{4}, 0.003 \mu \mathrm{M} \mathrm{ZnSO}, 0.017 \mu \mathrm{M}$ $\mathrm{Na}_{2} \mathrm{MoO}_{4}$ with nitrate $(0.5 \mathrm{mM}$ or $10 \mathrm{mM} \mathrm{KNO}$ ) or without nitrate ( $\mathrm{N}$ deprivation) with an equivalent concentration of potassium ions $\left(\mathrm{K}_{2} \mathrm{CO}_{3}\right)$. After 3 weeks of growth without nitrate, some of the plants were transferred for 1 week into $0.5 \mathrm{mM} \mathrm{KNO}_{3}$ (temporary nitrate provision). Other plants growing 2 weeks without nitrate followed by 1 week with $0.5 \mathrm{mM} \mathrm{KNO}_{3}$ were put again for 1 week into nutrient solution without nitrate (temporary nitrate starvation). In the last combination, seedlings starved 1 week with $\mathrm{NO}_{3}{ }^{-}$followed by 1 week with nitrate were transferred for 1 week into solution without nitrate and then for the last week into solution with nitrate (temporary nitrate re-supply). The nutrient solutions were aerated and replaced three times a week. All plants were grown in a growth chamber, under a 16-h photoperiod $\left(180 \mathrm{mmol} \mathrm{m}^{-2} \mathrm{~s}^{-1}\right)$ at $25{ }^{\circ} \mathrm{C}$ during the day and $22{ }^{\circ} \mathrm{C}$ during the night. For each treatment four samples $(50 \mathrm{mg})$ of each tissue from four different plants were taken for RNA extraction and immediately frozen in liquid nitrogen before storage at $-80{ }^{\circ} \mathrm{C}$.

\section{Quantitative real-time PCR}

Total RNA was extracted from cucumber tissues using TRI Reagent (Sigma) according to the manufacturer's instructions. To remove DNA contamination, RNA was digested with RNase-free DNase and reversely transcribed using oligo (dT) primers and the Transcriptor First Strand cDNA Synthesis Kit (Roche) according to the instructions. For each sample an RTcontrol (master mix without RT enzyme) was performed. Primer sets for SYBR Green I assays were designed using Lightcycler Probe Design software (Roche) or the Primer3 online tool (Table 1). The primers were designed very carefully to ensure amplification of single CSNRT1 isoforms. They were further used in standard RT-PCR reaction to check for size specificity of the amplicon size. The amplicons of newly identified cucumber genes were sequenced to confirm specificity of the PCR products.

To optimize the PCR amplification efficiency the best performing conditions (e.g., various annealing temperatures) were evaluated for each target and reference genes: CACS (Clathrin adaptor complex subunit, acc. no. GW881874), EF (Elongation factor, acc. no.
EF446145) and TIP41 (PPA2 activator, acc nom. GW881871). The stability of CACS, EF and TIP41 expression under different experimental conditions and in various plant organs has been already confirmed (Migocka and Papierniak 2011). The previous GeNorm analysis confirmed that all three genes showed also the most stable expression under different nitrate availability (data not shown). Amplification and melting curve analysis were performed with the LightCycler ${ }^{\circledR} 2.0$ System (32 capillaries format) in combination with the SYBR Green I Master Mix B (A\&A Biotechnology) in $10 \mu \mathrm{l}$ PCR reaction containing $1 \mu$ template, $1 \mu$ of each primer $(10 \mu \mathrm{M}), 5 \mu \mathrm{l}$ Master Mix and $2 \mu \mathrm{l}$ water. The thermal cycling conditions were as follows: $30 \mathrm{~s}$ at $95^{\circ} \mathrm{C}$, followed by 40 cycles of $10 \mathrm{~s}$ at $95^{\circ} \mathrm{C}, 10 \mathrm{~s}$ at $50-60{ }^{\circ} \mathrm{C}$ (Table 1), and $15 \mathrm{~s}$ at $72{ }^{\circ} \mathrm{C}$. Positive controls (DNA), a negative control (distilled water), and RT-negative controls (total RNA sample) were included in each run. To estimate PCR efficiency, sixfold target-specific dilution series (triplicates) were determined. To confirm the specificity of amplification, melting curve analysis was performed to identify putative unspecific PCR products (e.g., primer dimers, reaction mix contamination).

\section{Semiquantitative RT-PCR}

Total RNA was extracted from cucumber tissues with TRI Reagent (Sigma), digested with RNase-free DNase and used as a template in the one-step RT-PCR assay using Titan One Step RT-PCR System (Roche). The reaction assay was carried out at $50{ }^{\circ} \mathrm{C}$ for $30 \mathrm{~min}$ (1 cycle), $94{ }^{\circ} \mathrm{C}$ for $2 \mathrm{~min}$ ( 1 cycle), $94{ }^{\circ} \mathrm{C}$ for $30 \mathrm{~s}$, $50-60{ }^{\circ} \mathrm{C}$ (Table 1$)$ for $30 \mathrm{~s}$ and $68^{\circ} \mathrm{C}$ for $1 \mathrm{~min}(20-$ 30 cycles) and $68^{\circ} \mathrm{C}$ for $10 \mathrm{~min}(1 \mathrm{cycle})$. The genes encoding for CACS, EF and TIP41 (data not shown) were used as internal controls.

Database searching, prediction and analysis of CsNRT1 proteins

10 AtNRT1 cDNA sequences from the Aramemnon database (accession numbers are given in Table 2) were used as the initial query set to search against wholegenome shotgun reads available in the GenBank database containing the assembly of cucumber genome. BLASTN program was selected to compare cDNA queries against the DNA database and default BLASTN parameters were used to obtain high-stringency search results. The contigs containing sequences that significantly matched with 
Table 1 The list of primers used in all PCR reactions

\begin{tabular}{|c|c|c|c|c|c|}
\hline Gene & & $\begin{array}{l}\text { Product size } \\
\text { (bp) }\end{array}$ & $\begin{array}{l}\text { Cycle } \\
\text { number }^{\mathrm{a}}\end{array}$ & $\begin{array}{l}\text { Melting temperature } \\
\operatorname{Tm}^{\mathrm{b}}\end{array}$ & $\begin{array}{l}\text { Primers } \\
\text { efficiency }^{\mathrm{c}}\end{array}$ \\
\hline CsNRT1.1 & $\begin{array}{ll}\text { For } & \text { GACAGGAACTATGCATTTGGGGAAT } \\
\text { Rev } & \text { GCGCAATGTGATGACGACTCTA }\end{array}$ & 240 & 24 & 58 & 2,01 \\
\hline CsNRT1.2A & $\begin{array}{ll}\text { For } & \text { ATGCAGTACAAGTACAGACC } \\
\text { Rev } & \text { CCCATTTAATCCCATGCC }\end{array}$ & 205 & 28 & 56 & 1,89 \\
\hline CsNRT1.2B & $\begin{array}{ll}\text { For } & \text { TCAGCTGCTTTCAACAATAGG } \\
\text { Rev } & \text { GCTTGTGTTTGAATTGGACTT }\end{array}$ & 161 & 27 & 60 & 1,98 \\
\hline CsNRT1.2C & $\begin{array}{ll}\text { For } & \text { ATTGTATCGGTTGTGAACCA } \\
\text { Rev } & \text { AGGCCACTAAGAACACACATAA }\end{array}$ & 122 & 27 & 57 & 1,9 \\
\hline CsNRT1.3 & $\begin{array}{ll}\text { For } & \text { CATCAGTACAAAGACCAGCATTA } \\
\text { Rev } & \text { GCAAATGTGTCCTTGAGTTC }\end{array}$ & 168 & 24 & 56 & 2,0 \\
\hline CsNRT1.4A & $\begin{array}{ll}\text { For } & \text { GAAAGCAGAGATTAACGGTTG } \\
\text { Rev } & \text { TGGAAAGAAGGAAACATGTG }\end{array}$ & 240 & 24 & 56 & 2,0 \\
\hline CsNRT1.4B & $\begin{array}{ll}\text { For } & \text { CTTGGCTGAAGAGAAATGCTA } \\
\text { Rev } & \text { AACTGGTAATACTTTATACATAAAGCATC }\end{array}$ & 161 & 30 & 56 & 2,03 \\
\hline CsNRT1.5A & $\begin{array}{ll}\text { For } & \text { ATATCGGCGACCGATAAC } \\
\text { Rev } & \text { ACTACACTGGCAACTACAC }\end{array}$ & 230 & 24 & 58 & 1,95 \\
\hline CsNRT1.5B & $\begin{array}{ll}\text { For } & \text { GATGGGACTATTGATTGGCA } \\
\text { Rev } & \text { CTTCCCACATATAACCTTGTAGA }\end{array}$ & 152 & 27 & 58 & N/A \\
\hline CsNRT1.5C & $\begin{array}{ll}\text { For } & \text { TTATGGAGATCACAAGGAAAGAAG } \\
\text { Rev } & \text { CGGTACTATTGAAATGTCATCC }\end{array}$ & 179 & 33 & 60 & N/A \\
\hline CsNRT1.8 & $\begin{array}{ll}\text { For } & \text { CGTTGTCTCTGCGGCGAA } \\
\text { Rev } & \text { GTTCACTCCTTGCTCTTTATCACTT }\end{array}$ & 190 & 27 & 60 & 2,02 \\
\hline CsNRT1.9 & $\begin{array}{ll}\text { For } & \text { TTTACTACAAGGAGTTCCCTGA } \\
\text { Rev } & \text { CGATACCAAGAAATAGAAGTAATCCA }\end{array}$ & 153 & 25 & 56 & 1,96 \\
\hline CsNRT1.10 & $\begin{array}{ll}\text { For } & \text { TGGGAAGATTCTTATGAAGTGC } \\
\text { Rev } & \text { CTCGTCAAATTTACACATTGGT }\end{array}$ & 185 & 30 & 56 & N/A \\
\hline$C A C S$ & $\begin{array}{ll}\text { For } & \text { TGGGAAGATTCTTATGAAGTGC } \\
\text { Rev } & \text { CTCGTCAAATTTACACATTGGT }\end{array}$ & 171 & 24 & 56 & 2,0 \\
\hline$E F$ & $\begin{array}{ll}\text { For } & \text { ACTTTATCAAGAACATGATTAC } \\
\text { Rev } & \text { TTCCTTCACAATTTCATCG }\end{array}$ & 556 & 25 & 56 & 1,98 \\
\hline TIP41 & $\begin{array}{ll}\text { For } & \text { CAACAGGTGATATTGGATTATGATTATAC } \\
\text { Rev } & \text { GCCAGCTCATCCTCATATAAG }\end{array}$ & 221 & 25 & 56 & 1,94 \\
\hline
\end{tabular}

\footnotetext{
${ }^{\mathrm{a}}$ The number of cycles used in semiquantitative RT-PCR assays

${ }^{\mathrm{b}}$ Melting temperatures used in the annealing steps of semiquantitative RT-PCR assays and real-time PCR analysis

${ }^{\mathrm{c}}$ The efficiency of real-time PCR reactions with primers used for expression analyses of CsNRTs under differential nitrate availability; N/A, not available
}

AtNRT1 cDNAs were retrieved from the database and further analyzed using FGENESH and FGENESH+ tools (Softberry, Inc., Mount Kisco, New York; www. softberry.com) to obtain information on complete open reading frames (ORFs) of cucumber NRT1 genes. Functional annotations were made by BLASTP searches against GenBank protein data sets with final full-length NRT1 protein sequences. The sequences of NRT1 proteins from other plants were retrieved from the GenBank database (Vitis vinifera), Gramene database (Brachypodium diastychon, Sorghum bicolor, Zea mays, Oryza sativa) and
The Populus Genome Integrative Explorer PopGenIE (Populus trichocarpa). Protein sequence alignments and analysis were conducted using ClustalW and the phylogenetic trees were constructed with MEGA5.0 software (Tamura et al. 2011) using the Maximum Likelihood method.

Statistical analysis

Unpaired and paired student's $t$ tests and ANOVA (Excel) were used for statistical analyses. 
Table 2 The genomic organization of genes encoding Nitrate transporters 1 (NRT1) in cucumber. The genes were identified through the screening of the whole-genome shotgun reads database (GenBank) using the queries of AtNRT1 cDNAs. The structure of each gene was determined using FGENESH or FGENESH+ programs available on softberry.com

\begin{tabular}{|c|c|c|c|c|c|c|c|c|}
\hline Gene & $\begin{array}{l}\text { Cucumis } \\
\text { source gene }\end{array}$ & $\begin{array}{l}\text { Ortholog } \\
\text { locus }\end{array}$ & $\begin{array}{l}\text { Position of } \\
\text { predicted NRT1 } \\
\text { genes }\end{array}$ & $\begin{array}{l}\text { Length of } \\
\text { nucleotide }\end{array}$ & $\begin{array}{l}\text { Length } \\
\text { of } \\
\text { protein }\end{array}$ & $\begin{array}{l}\text { Number of } \\
\text { predicted } \\
\text { exons }\end{array}$ & $\begin{array}{l}\text { Number of } \\
\text { predicted } \\
\text { introns }\end{array}$ & $\begin{array}{l}\text { Coverage } \\
\%\end{array}$ \\
\hline AtNRT1.1 & ACHR01013570 & Atlg12110 & $16560-23201$ & -chain 1782 bp & 593 aа & 5 & 4 & 89 \\
\hline \multirow[t]{3}{*}{ AtNRT1.2 } & ACHR01000321 & At1g69850 & $58510-62933$ & -chain 1662 bp & 553 aа & 4 & 3 & 68 \\
\hline & ACHR01001662 & At1g69850 & $48867-52778$ & +chain 1719 bp & 572 aa & 5 & 4 & 76 \\
\hline & ACHR01009250 & At1g69850 & $15544-21379$ & +chain 1701 bp & 566 aа & 5 & 4 & 71 \\
\hline AtNRT1.3 & ACHR01015650 & At3g21670 & $10233-12797$ & -chain 1770 bp & 589 aа & 5 & 4 & 85 \\
\hline \multirow[t]{2}{*}{ AtNRT1.4 } & ACHR01002604 & At2g26690 & $69336-72702$ & -chain 1746 bp & 581 aа & 6 & 5 & 84 \\
\hline & ACHR01013747 & At2g26690 & $2026-5621$ & -chain 1701 bp & 566 aа & 7 & 6 & 93 \\
\hline \multirow[t]{4}{*}{ AtNRT1.5 } & ACHR01012613 & Atlg32450 & 10824-16019 & - chain 1764 bp & 587 aa & 5 & 4 & 81 \\
\hline & ACHR01010533 & At1g32450 & $4863-9025$ & +chain 1923 bp & 640 aа & 6 & 5 & 79 \\
\hline & ACHR01000127 & At1g32450 & $61715-65506$ & +chain 1848 bp & 615 aa & 6 & 5 & 77 \\
\hline & ACHR01011136 & At1g32450 & $1564-4221$ & -chain 1986 bp & 661 aa & 5 & 4 & 73 \\
\hline AtNRT1.6 & ACHR01000323 & At1g27080 & $46359-49781$ & +chain 1797 bp & 598 aа & 4 & 3 & 30 \\
\hline AtNRT1.7 & ACHR01000323 & At1g69870 & $46359-49781$ & +chain 1797 bp & 598 aа & 4 & 3 & 36 \\
\hline \multirow[t]{4}{*}{ AtNRT1.8 } & ACHR01000127 & At4g21680 & $61715-65506$ & +chain 1848 bp & $615 \mathrm{aa}$ & 6 & 5 & 75 \\
\hline & ACHR01010533 & At4g21680 & $4863-9025$ & +chain 1923 bp & 640aa & 6 & 5 & 79 \\
\hline & ACHR01011136 & At4g21680 & $1564-4221$ & -chain 1986 bp & 661 aa & 5 & 4 & 67 \\
\hline & ACHR01012613 & At4g21680 & 10824-16019 & -chain 1764 bp & 587 aа & 5 & 4 & 62 \\
\hline AtNRT1.9 & ACHR01001662 & Atlg18880 & $29665-32150$ & -chain 1803 bp & 600 aa & 5 & 4 & 79 \\
\hline AtNRT1.10 & ACHR01001662 & At5g62680 & $35145-37352$ & -chain 1770 bp & 589 aа & 4 & 3 & 66 \\
\hline
\end{tabular}

\section{Results}

Selection of contigs, prediction and annotation of CSNRT1 genes

Using 10 Arabidopsis thaliana cDNAs encoding AtNRT1-10 proteins as the query sequences, we selected 12 contigs among cucumber whole genome shotgun reads in the GenBank database, that significantly matched with AtNRT1s (Table 2). All selected contigs were scanned for potential genes using the FGENESH program and, in some cases, the version of this tool (FGE$\mathrm{NESH}+$ ) which uses additional information from the available protein homolog and thus improves the accuracy of gene identification. As a result, 13 sequences of cucumber that significantly matched with the query cDNAs (query coverage $>60 \%$ ) were identified: one homolog of AtNRT1.1 (CSNRT1.1), three homologs of AtNRT1.2 (CsNRT1.2A, CsNRT1.2B and CsNRT1.2C), one homolog of AtNRT1.3 (CsNRT1.3), two homologs of AtNRT1.4 (CsNRT1.4A and CsNRT1.4B), three homologs of AtNRT1.5 (CsNRT1.5A, CsNRT1.5B and CsNRT1.5C), one homolog of AtNRT1.8 (CsNRT1.8), one homolog of AtNRT1.9 (CsNRT1.9) and one homolog of AtNRT1.10 (CsNRT1.10). In addition, one putative cucumber homolog of AtNRT1.6 and AtNRT1.7 was identified within contig ACHR01000323 (Table 2), but the coverage of these Arabidopsis thaliana and cucumber sequences was significantly lower $(<37 \%)$ in comparison with other NRT1 genes. Thus, only closely related genes showing a high score with the AtNRT1 query sequences ( $>60 \%$ ) were subjected to further experimental analysis.

The genomic organization of newly identified cucumber CsNRT1s is presented in Table 2. The cDNAs encoding putative members of the cucumber nitrate transporters 1 family are $1662 \mathrm{bp}-1986 \mathrm{bp}$ long and consist of 4 to 6 exons (Table 2). Hence, the putative protein sequences are composed of 552 to 661 amino acid residues. The phylogenetic analysis of NRT1 proteins from cucumber and other dicots (Arabidopsis thaliana, Vitis vinifera, Populus trichocarpa) and monocots (Oryza sativa, Brachypodium diastychon, Zea mays, Sorghum bicolor) allowed for an 
initial, careful annotation of cucumber proteins (Fig. 1). According to the analysis, all NRT1 proteins in plants fall into two distinct phylogenetic groups: one containing NRT1.1-NRT1.4 proteins and the other comprising transporters NRT1.5-NRT1.9 (Fig. 1). Both groups can be further divided into two distinct clusters branching of common ancestor. In the first group, NRT1.1, NRT1.3 and NRT4 proteins cluster together, whereas NRT1.2 proteins fall into separate cluster (Fig. 1). The second group is divided into one cluster containing NRT1.6, NRT1.7 and NRT1.9 proteins and another cluster comprising NRT1.5 and NRT1.8-like transporters (Fig. 1). Further analysis of the phylogenetic relations between plant NRT1 proteins suggests that NRT1.2s and NRT1.4s as well as NRT1.6-1.7 and NRT1.9-like proteins had the same protein ancestors. Moreover, NRT1.8-like proteins, which are present only in dicots, could have evolved from NRT1.5-like transporters (Fig. 1).

\section{Organ expression pattern of CsNRT1s}

The transcription profile of cucumber NRT1s in different organs of young or older plants suggests that none of the identified genes is a non-functional pseudogene. All of the computationally predicted genes were clearly expressed during cucumber development, which validates the notion that they correspond to real genes (Fig. 2). Most of the transcripts were clearly detected in vegetative tissues and inflorescences, except for CsNRT1.5B and CsNRT1.5C, which were expressed almost solely in flowers. A distinct organ expression pattern was also observed for CsNRT1.10, since the transcription of the gene occurred predominantly in tendrils and, at a lower rate, in flowers. In contrast, CsNRT1.1, CsNRT1.3, CsNRT1.5A and CsNRT1.8 were expressed in all 17 cucumber organs (Fig. 2). These commonly expressed genes are likely to be essential for fundamental cellular processes. Among them, CsNRT1.3 was particularly highly expressed in flowers and young

Fig. 1 Unrooted phylogenetic tree of the NRT1-like transporters identified in cucumber and other dicots and monocots. The multiple alignment of all proteins was performed using ClustalW. The accession numbers of all proteins are given in Supplementary File S1. The tree was constructed by the MEGA5.1 software (Tamura et al. 2011) using Maximum Likelihood method with 1.000 bootstrap replicate trees. The distance scale represents the evolutionary distance, expressed as the number of substitutions per amino acid

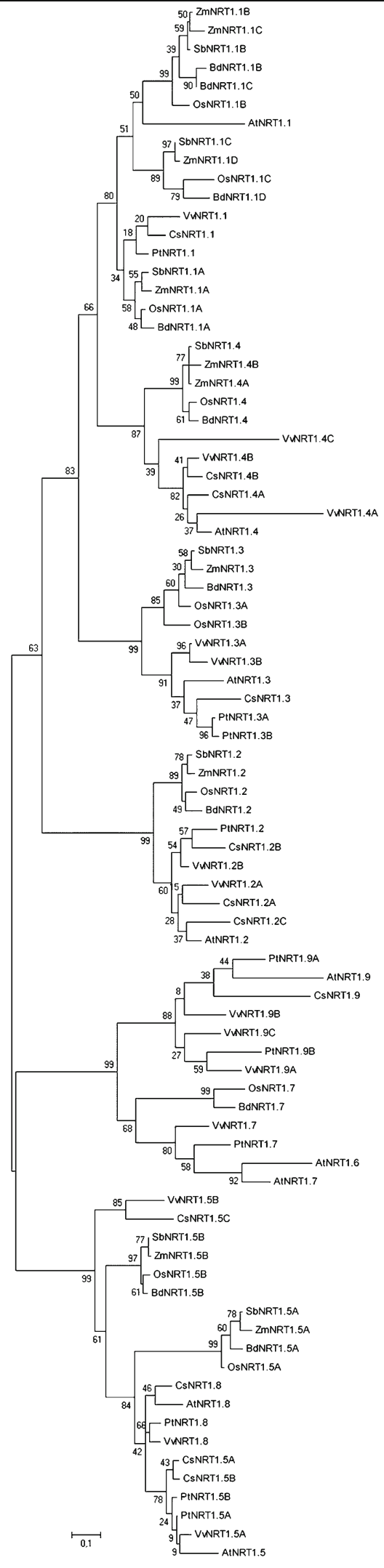


1-week-old plants

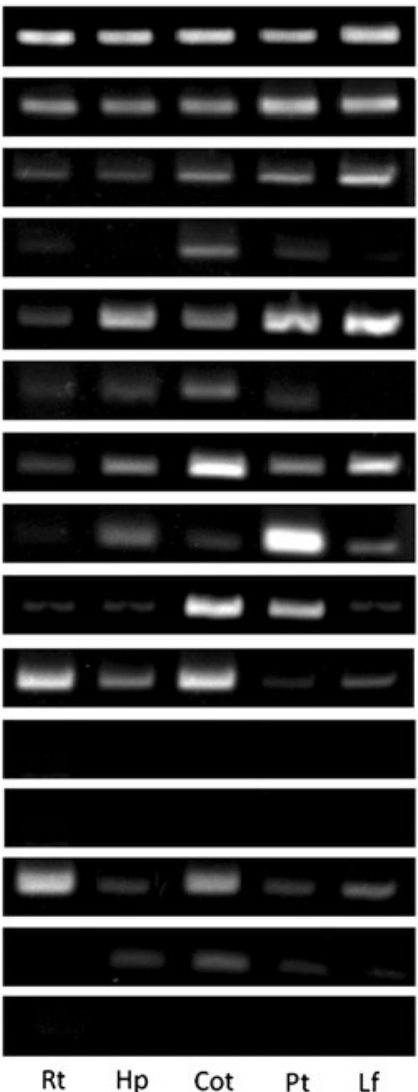

8-week-old plants

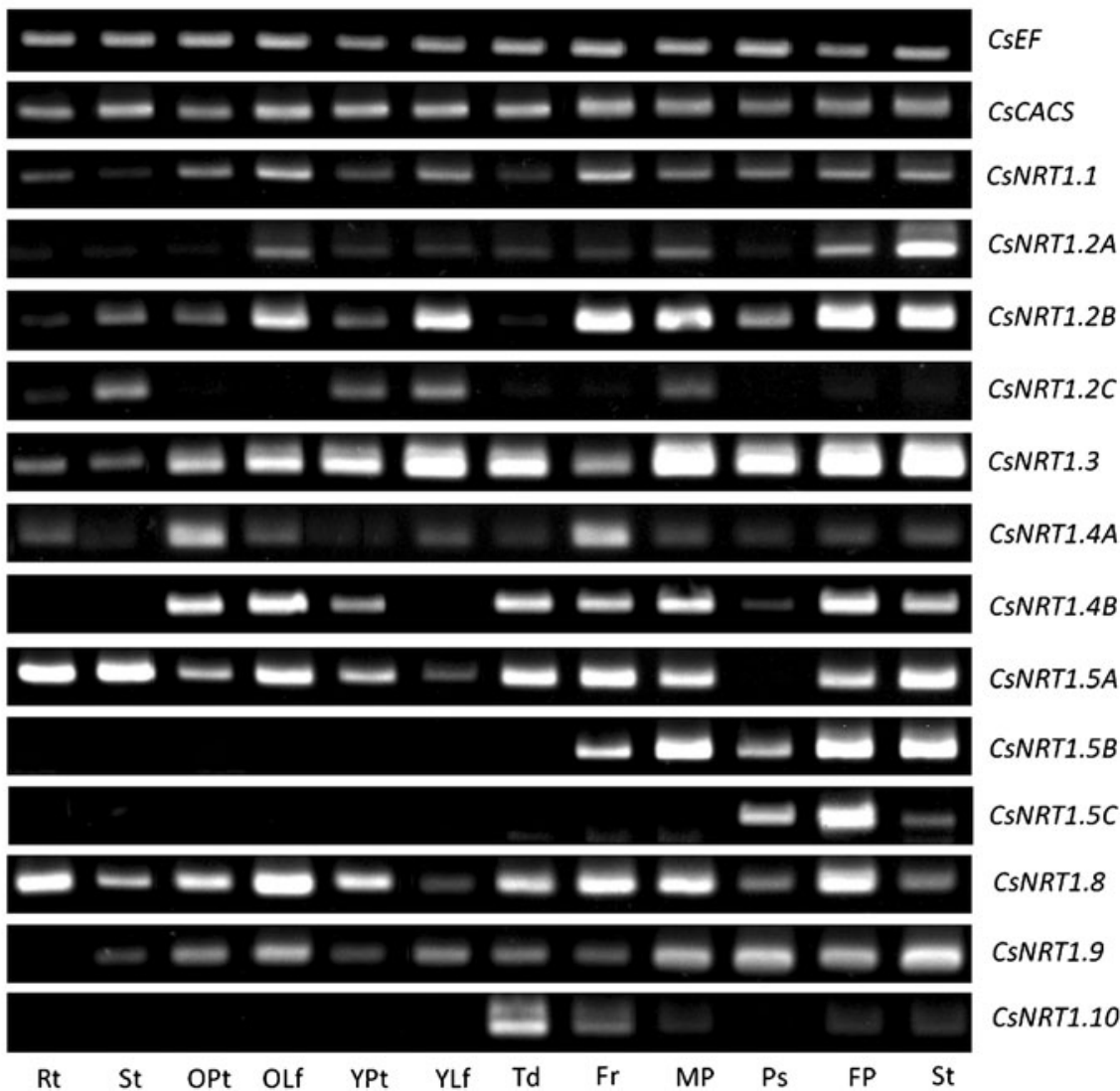

Fig. 2 Semiquantitative RT-PCR analysis of the organ expression pattern of CsNRT1s in 1-week-old and 8-week-old cucumber plants. Genes encoding for elongation factor $(\mathrm{EF} \alpha)$ and CACS were used as internal controls. Rt-roots, Hp-hypocotyls,

leaves, suggesting that it was of high importance for the development of all flower parts and expanding leaves. Interestingly, the transcriptional profiles of multiplied cucumber homologs of AtNRT1.2, AtNRT1.4, AtNRT1.5 and $A t N R T 1.8$ were different, suggesting that following duplication or triplication from the common gene ancestor, the novel isoforms gained some new physiological functions. For instance, CsNRT1.4A appears to be highly specific for petioles and fruits, whereas CsNRT1.4B was clearly expressed in 10 different organs of young and older plants.

Transcription profile of CsNRT1s under different nitrate supply and re-supply

All AtNRT1s are considered low-affinity transporters except one member of the NRT1 family, AtNRT1.1
Cot-cotyledons, Pt-petiole, Lf-leaf, S-stem, Opt-old petiole, OLf-old leaf, YPt-young petiole, YLf-young leaf, Td-tendril, Fr-fruit, MP-male perianth, St-stamen, FP-female perianth, Pspistil

(CHL1), which is a dual-affinity transporter with a $K_{\mathrm{m}}$ of $\sim 50 \mu \mathrm{M}$ for its high-affinity mode and $\sim 5 \mathrm{mM}$ for its low-affinity mode (Liu et al. 1999). In order to determine whether the cucumber members of the NRT1 family are involved in nitrate transport within plant cells, we tested how nitrogen deficiency, low or high nitrate as well as variable nitrate supply affect $C S N R T 1 s$ expression.

\section{CsNRT1.1}

As shown in Figs. 3 and 4, CsNRT1.1 was widely, but more or less differentially expressed in all tested samples (roots, stems, cotyledons, petioles and leaves) of 4-week-old cucumbers grown under different nitrate regimes. In roots, CSNRT1.1 expression was downregulated under high nitrate, whereas in stems the level of the transcript significantly increased upon $\mathrm{N}$ 

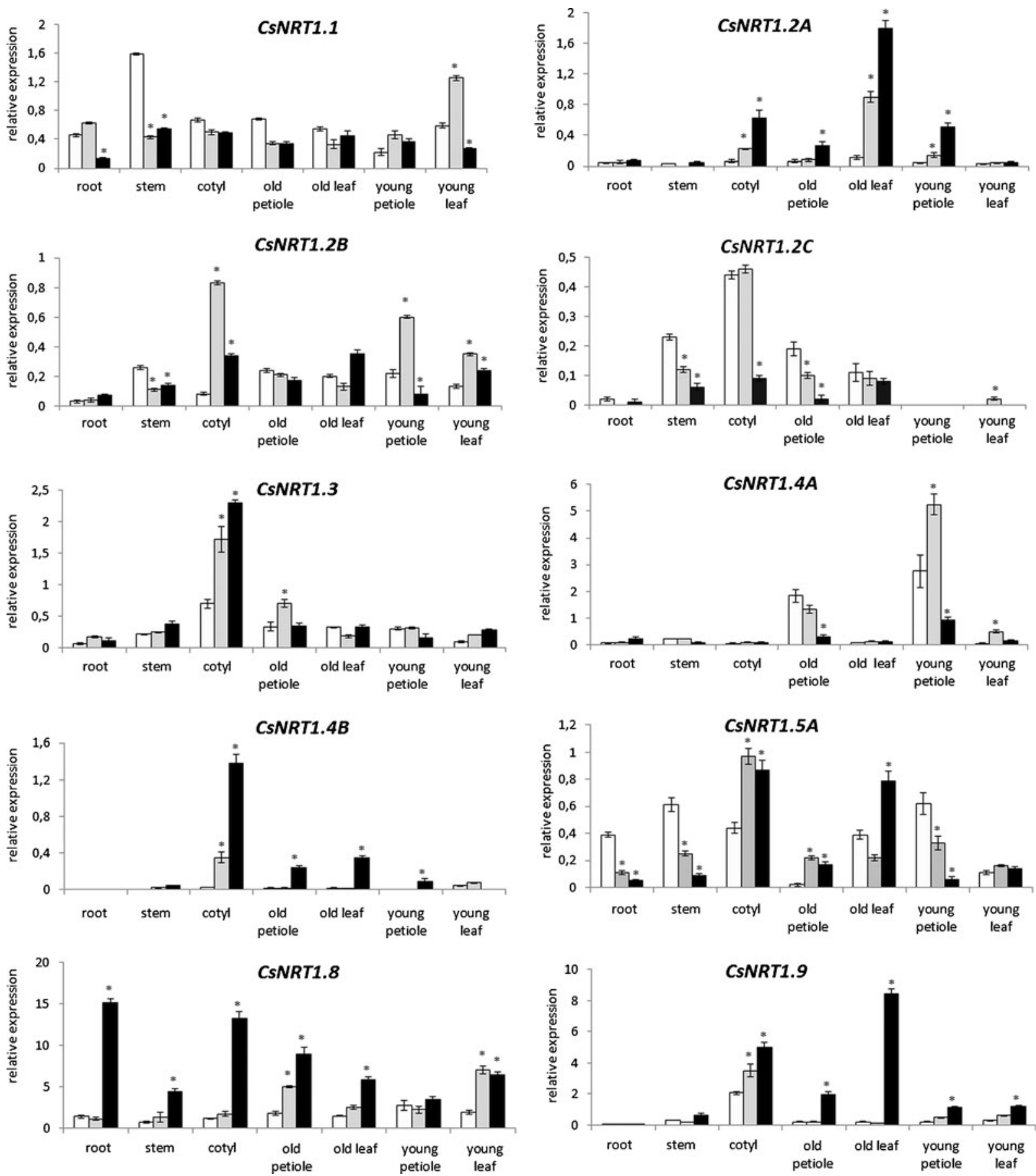

Fig. 3 Real-time (qPCR) expression analyses of CsNRT1s in roots, stems, cotyledons, old and young petioles and old and young leaves of 4-week-old cucumbers. Highly reliable reference genes (CACS, clathrin adapter complex subunit, EF, elongation factor, TIP41, PPA2 activator) were used to normalize the results of $\mathrm{qPCR}$ analysis, using the $2^{-(\Delta \mathrm{Ct})}$ method. The

normalization based on three different reference genes showed very similar results. The presented values were normalized to $C A C S$ transcript levels in the same samples. Asterisks indicate significant differences between plants grown under $\mathrm{N}$ deprivation (white bars) and plants grown upon constant $0.5 \mathrm{mM}$ (grey bars) or $10 \mathrm{mM}$ (black bars) $\mathrm{NO}_{3}{ }^{-}$provision $(P<0.05)$ 

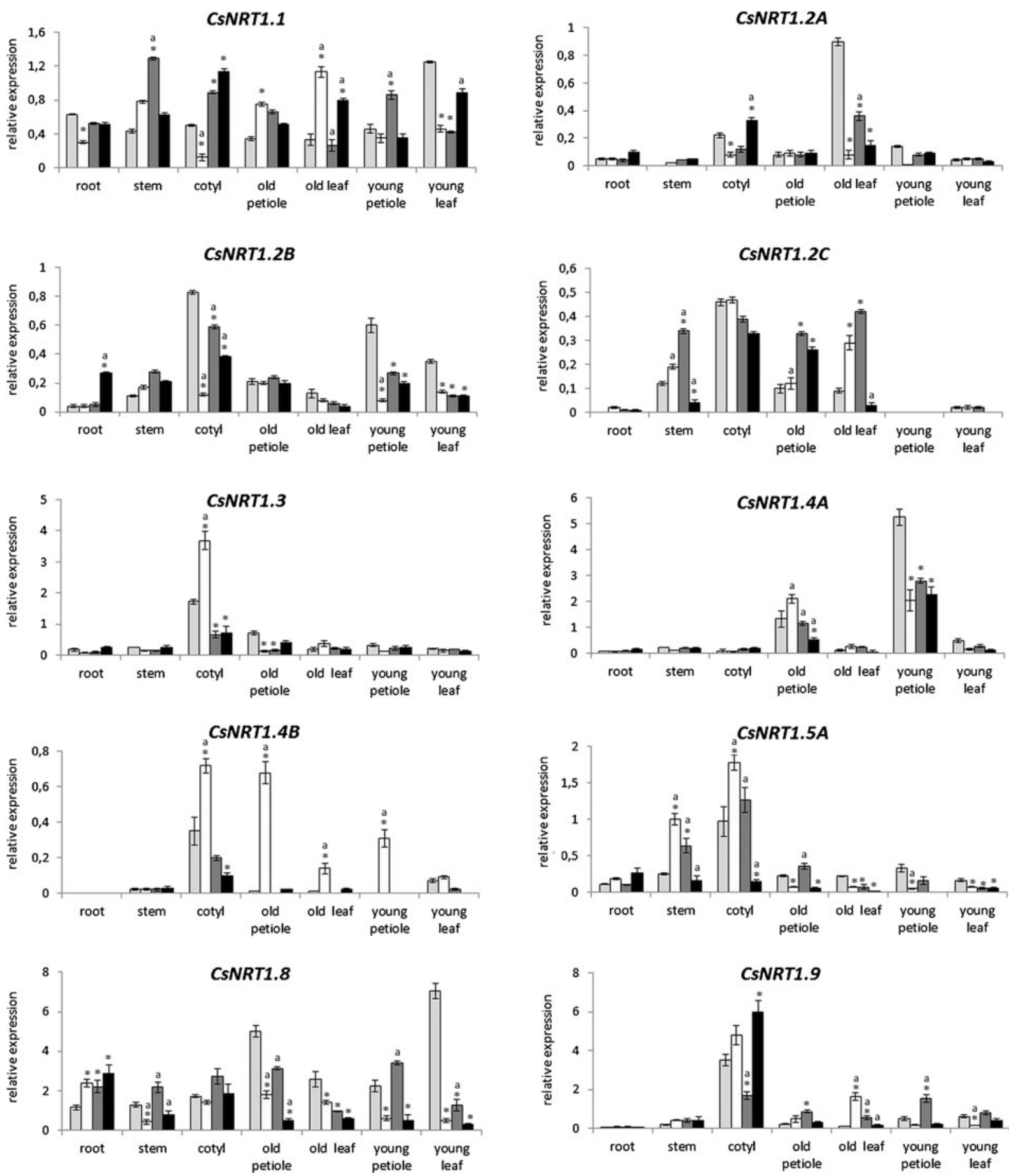

Fig. 4 Quantitative (qPCR) analysis of $C s N R T 1$ genes expression in roots, stems, cotyledons, old and young petioles and old and young leaves of 4-week-old cucumbers grown in the constant $0.5 \mathrm{mM}$ (light grey bars) or varying low nitrate supply: upon temporary nitrate provision (white bars), upon temporary nitrate

starvation (dark grey bars) or upon temporary nitrate re-supply (black bars). Asterisks indicate significant differences between plants grown under constant and varying nitrate supply ( $P$-values $\leq 0.05)$. Bars headed by letters " $a$ " indicate significant differences between plants grown in varying nitrate regimes $(P$-values $\leq 0.05)$ 
deprivation or temporary nitrate starvation (Figs. 3 and 4). In cotyledons, CsNRT1.1 transcript was affected only during variable nitrate supply, reaching the highest level under temporary nitrate starvation or resupply and the lowest abundance under temporary nitrate provision (Fig. 4). In contrast, during the latter conditions, the expression of the gene was significantly enhanced in old petioles and old leaves (Fig. 4). The re-supply of nitrate following $\mathrm{N}$ deprivation caused a significant increase in CSNRT1.1 transcript in old but not in young leaves, where the transcript level decreased markedly under temporary nitrate provision or starvation. In young petioles, the level of CSNRT1.1 mRNA increased upon temporary nitrate starvation (Fig. 4). Steady nitrate provision or deprivation did not affect CSNRT1.1 expression in cotyledons, old petioles or old leaves, or in young petioles (Fig. 3).

\section{CsNRT1.2s}

Similarly to organ expression patterns, the expression profiles of three cucumber homologs of AtNRT1.2 under variable nitrate provision were different. CsNRT1.2A mRNA was highly abundant in cotyledons, old and young petioles and in old leaves of plants grown in high nitrate (Fig. 3). Its expression in cotyledons was also enhanced under temporary nitrate re-supply (Fig. 4). In contrast, the transcript's abundance markedly decreased in old leaves under variable nitrate supply (Fig. 4). CsNRT1.2A mRNA was also hardly detectable in young petioles of plants grown upon temporary nitrate provision (Fig. 4). In contrast to CsNRT1.2A, which was the most highly induced under $10 \mathrm{mM}$ nitrate, CsNRT1.2B expression in cotyledons, young petioles and young leaves was more pronounced under low $(0.5 \mathrm{mM}) \mathrm{NO}_{3}{ }^{-}$level (Fig. 3). Additionally, the CsNRT1.2B mRNA was clearly detected in all organs except for the roots of plants grown under temporary nitrate provision (Fig. 4). The level of CsNRT1.2B transcript was also markedly reduced in cotyledons and young petioles upon variable nitrate supply (Fig. 4). Surprisingly, the CsNRT1.2C transcription profile was distinct from both CsNRT1.2A and CsNRT1.2B expression patterns. The third cucumber homolog of AtNRT1.2 was considerably expressed under $\mathrm{N}$ deprivation or low nitrate in stem, cotyledons and old petioles (Fig. 3). Hardly any CsNRT1.2C mRNA was detected in roots, young petioles or young leaves. High nitrate generally down- regulated CsNRT1.2C expression except for the old leaves, where $10 \mathrm{mM} \mathrm{NO}_{3}{ }^{-}$had little influence on the transcript level. In addition, CsNRT1.2C $m R N A$ was particularly elevated under temporary nitrate starvation in stem, old leaves and old petioles or upon temporary nitrate supply in old leaves (Fig. 4). On the other hand, upon temporary nitrate re-supply the expression of gene was markedly lower or higher in old petioles or stem and old leaves, respectively (Fig. 4).

\section{CsNRT1.3}

The transcript of CSNRT1.3 was relatively low in all tested samples except for the cotyledons, where it significantly increased upon continuous low or high nitrate provision as well as upon temporary low nitrate supply (Figs. 3 and 4). In contrast, the expression of CsNRT1.3 in old petioles was markedly reduced upon temporary low nitrate provision/starvation, whereas it was more enhanced under continuous $0.5 \mathrm{mM} \mathrm{NO}_{3}{ }^{-}$supply (Figs. 3 and 4). The CSNRT1.3 transcript abundance in other cucumber organs was not significantly affected under nitrogen deficiency or by the availability of external nitrate.

\section{CsNRT1.4s}

Similarly to CsNRT1.2s, two cucumber homologs of AtNRT1.4 also showed different expression patterns under variable nitrate supply. CsNRT1.4A transcript was virtually specific only for both young and old petioles, showing the highest expression under $\mathrm{N}$ deprivation or continuous low nitrate supply (Fig. 3). The gene was evidently down-regulated under high nitrate and, in young petioles, under variable nitrate provision (Figs. 3 and 4). In contrast, CsNRT1.4B transcript was almost exclusively expressed under high nitrate level or temporary low nitrate provision, and reached the highest peak in cotyledons (Figs. 3 and 4). Beside petioles and cotyledons, CsNRT1.4B mRNA was also clearly detectable in leaves (Figs. 3 and 4).

\section{CsNRT1.5A}

Among three cucumber homologs of AtNRT1.5, CsNRT1.5B and CsNRT1.5C were exclusively expressed in reproductive parts of the plant: flowers and fruits (Fig. 2). Hence only CsNRT1.5A expression was analyzed in roots, stems, cotyledons, petioles and leaves of 
4-week-old cucumbers grown under different nitrate regimes. In roots, stems and young petioles, CsNRT1.5A was considerably expressed upon constant $\mathrm{N}$ deprivation and down-regulated under nitrate (Fig. 3). In contrast, the expression of the gene was enhanced under continuous high or high and low nitrate provision in old leaves and cotyledons, respectively (Fig. 3). Under variable low nitrate supply, CsNRT1.5A was predominantly expressed in stems and cotyledons, showing the highest expression under temporary nitrate provision/starvation (Fig. 4).

\section{CsNRT1.8}

Taking into account amino acid composition and phylogeny, NRT1.5 and NRT1.8 are very closely related proteins (Fig. 1), suggesting that they could contribute to similar physiological processes in plant cells. Despite the organ expression profiles of CSNRT1.5A and CSNRT1.8 were similar, the transcription profiles of both genes under different nitrate regimes were quite distinct. The CSNRT1.8 transcript was present in nearly every tested organ, though its abundance was considerably higher in roots and, to a lesser extent, in stems, cotyledons, old petioles and old leaves under high nitrate supply (Fig. 3). Of all CSNRT1s tested under different nitrate supply, CsNRT1.8 was the most highly expressed gene (particularly in roots and cotyledons) upon $10 \mathrm{mM}$ nitrate provision (Fig. 3). The gene transcription was generally repressed under $\mathrm{N}$ deprivation or low nitrate in all cucumber organs except for young petioles or, in the case of low nitrate, young leaves (Fig. 3). In stems, petioles and leaves, CsNRT1.8 also revealed a lower expression upon temporary low nitrate provision, starvation or re-supply (Fig. 4). In contrast, in roots the level of $C s N R T 1.8$ transcript was higher under variable nitrate supply then upon the constant $0,5 \mathrm{mM}$ nitrate provision (Fig. 4).

\section{CsNRT1.9}

Among the two last cucumber CsNRT1s, CsNRT1.9 and CSNRT1.10, the latter was specific only for tendrils and fruits (Fig. 2). In contrast, CsNRT1.9 expression was clearly detectable in all vegetative organs except for roots (Figs. 2, 3 and 4); hence only this gene was analyzed in cucumber plants subjected to different nitrate provision. CSNRT1.9 was the most highly expressed upon high nitrate provision (Fig. 3). In fact, only in cotyledons was CsNRT1.9 mRNA clearly detectable upon continuous low nitrate supply or $\mathrm{N}$ deprivation (Fig. 3). Under variable nitrate provision, the transcript level was enhanced predominantly in cotyledons of plants grown in temporary nitrate re-supply, in old leaves of plants grown upon temporary nitrate supply and in young petioles of cucumbers grown upon temporary nitrate starvation (Fig. 4). In contrast, in cotyledons and young leaves the CSNRT1.9 mRNA was markedly reduced under temporary nitrate starvation or provision, respectively (Fig. 4).

\section{Discussion}

With completion of the Cucumis sativus genome projects in 2009 (Huang et al. 2009) and 2011 (Wóycicki et al. 2011), we now have another powerful model organism for studying functions, regulations, and interactions of genes in an entire genome of higher plants. Whole gene families can be rapidly identified and examined in greater detail in Cucumis sativus, allowing for a better overview on gene functions and regulations during cucumber growth, development and response to environmental changes. Taking advantage of the progress in plant genome analyses, we aimed to identify and analyze genes encoding cucumber nitrate transporters NRT1. For a long time the comparison of sequence information across species has brought new insights into the evolution of organisms; hence an essential source of additional information used through the screening of the cucumber genome was the previous identification and sequencing of the Arabidopsis thaliana cDNAs encoding the nitrate transporter 1 family. Using AtNRT1 cDNAs as the query sequences, we succeeded in the selection of contiguous DNA segments containing putative cucumber homologs encoding NRT1 proteins (Table 2). Some of the AtNRT1s homologs were represented by two (CsNRT1.4) or even three (CsNRT1.2, CsNRT1.5) genetic isoforms in the cucumber genome (Table 2). It may be suggested that at least three CsNRT1 genes underwent additional duplication or triplication events. Multiplication among NRT1s has already been reported. For AtNRT1.1, there is one homolog in cucumber and poplar, whereas in the grasses, multiplied closely related NRT1.1-like genes have been identified: three in rice $(O s N R T 1.1 A / B / C)$ and sorghum (SbNRT1.1A/B/ $C)$ and four in maize $(Z m N R T 1.1 A / B / C / D)$ and Brachypodium (BdNRT1.1A/B/C/D) (Plett et al. 2010) (Fig. 1). For AtNRT1.3 and AtNRT1.4, there is at least one 
member from grass species with an extra representatives for NRT1.3 and NRT1.4 in rice, maize (Plett et al. 2010) and $V$. vinifera (GenBank) (Fig. 1). Similarly to CsNRT1.5s, AtNRT1.5 is also represented by multiplied homologs in poplar (PtNRT1.5A/B), rice (OsNRT1.5A/

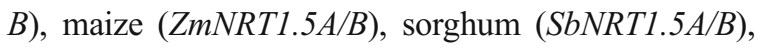
Brachypodium (BdNRT1.5A/B) (Plett et al. 2010) and grape (GenBank) (Fig. 1). By contrast, for AtNRT1.2, there is only one member in poplar or grasses (Plett et al. 2010), while three and two homologs have been identified in the cucumber (Table 2) and $V$. vinifera genomes, respectively (Fig. 1). Cucumber NRT1s were different from AtNRT1s not only due to the multiplication of some CSNRT1 sequences but also due to the deletion of one of the two members of the NRT1 family, NRT1.6 or $N R T 1.7$, and a significant evolutionary change in the remaining homolog (Table 2). Similarly to multiplication, deletion events among NRT1 families from various species have also been reported. For instance, there is no AtNRT1.4-like gene and only one homolog of both, AtNRT1.6 and AtNRT1.7 in poplar (Plett et al. 2010). Also maize and sorghum lack representatives of the NRT1.6 and NRT1.7 genes (Plett et al. 2010). Similarly, NRT1.6-like gene was not found in the genome of Vitis vinifera. Due to the lowest coverage of Arabidopsis NRT1.6 and NRT1.7 with their cucumber homolog, the cucumber gene was not subjected to further experimental analyses. Additional experimental sequencing and expression analysis are required to include the cucumber homolog in the NRT1 family.

The function of NRT1 putative proteins has been determined experimentally mainly in Arabidopsis thaliana. In this work, we aimed to shed light on cucumber NRT1 physiological function through wide expression analyses of CsNRT1s. As a result, we selected two phylogenetically close relatives that were specific only for reproductive organs (flowers and/or fruits): CsNRT1.5B and CsNRT1.5C (Fig. 2). In A. thaliana, the only NRT1 highly specific for reproductive organs is NRT1.6, which transports $\mathrm{NO}_{3}{ }^{-}$from maternal tissue to developing embryos (Almagro et al. 2008). It remains to be elucidated whether the evolution of CSNRT1.5B and CSNRT1.5C following triplication of $C S N R T 1.5$ led to the functionally novel proteins that substitute for NRT1.6 in cucumber. Like CsNRT1.5B and CsNRT1.5C, CsNRT1.10 also revealed quite a distinct organ expression profile, showing that the protein encoded by this gene is present almost exclusively in tendrils and fruits (Fig. 2). In addition, the Arabidopsis NRT1.10 was already shown to be a peptide transporter expressed exclusively in funicle, which is required for the proper development of seeds (Tsay et al. 2005). Therefore both Arabidopsis and cucumber NRT1.10 can be functional homologs responsible for the proper ratio of different forms of nitrogen within seeds and embryos. However, it remains to be established whether CsNRT1.10 is a nitrate or peptide transporter.

The remaining cucumber NRT1s were clearly expressed in most of the vegetative tissues and inflorescences (Fig. 2). According to their expression patterns under different levels of nitrate supply, the CsNRT1s can be carefully divided into high nitrate-inducible, low nitrate-inducible or nitrate-repressible genes depending on the organ tested. For instance, CsNRT1.1 is clearly up-regulated by $\mathrm{N}$ deprivation in shoots, but downregulated under high nitrate in roots (Fig. 3). In roots, low nitrate significantly stimulated AtNRT1.1 (Okamoto et al. 2003), whereas CSNRT1.1 expression under $\mathrm{N}$ deprivation and $0.5 \mathrm{mM} \mathrm{KNO}_{3}$ was similar. The expression of Arabidopsis and cucumber NRT1.1s in response to nitrate provision was also quite different in shoots: AtNRT1.1 was clearly induced by low nitrate (Okamoto et al. 2003) whereas CsNRT1.1 expression was considerably higher under $\mathrm{N}$ deprivation (Fig. 3). In fact, both genes were studied under different time courses of nitrate supply, which could explain the alterations in their transcriptional responses. Nevertheless, different, organdependent responses of CSNRT1.1 to nitrate deficiency, shortage or excess as well as the relatively wide distribution of the transcript in plant tissues suggest that NRT1.1 may be employed in multiple responses of plant cells to nitrate. Indeed, Arabidopsis NRT1.1 was shown to mediate high- and low-affinity nitrate transport (Wang et al. 1998; Liu et al. 1999; Liu and Tsay 2003), to function as an $\mathrm{NO}_{3}{ }^{-}$sensor (Ho et al. 2009) and to facilitate nitrate-regulated basipetal auxin transport out of lateral roots, leading to the repression of root growth at low nitrate availability (Krouk et al. 2010).

AtNRT1.2 has three representatives in the cucumber genome. Multiplied genes that exist after a gene multiplication (e.g. duplication, triplication) event usually code for proteins with a similar role and/or structure, becoming redundant for an essential function. However, the expression pattern of all three cucumber isoforms homologous to AtNRT1.2 were quite distinct, suggesting that the novel NRT1.2-like proteins bring some new physiological benefits to cucumber plants. It was initially shown that the expression of AtNRT1.2 was constitutive and occurred predominantly in root epidermis, 
indicating that, similarly to NRT1.1, NRT1.2 is also involved in nitrate uptake from the soil (Huang et al. 1999). A few years later, Okamoto et al. (2003) also revealed the constitutive expression of AtNRT1.2 in shoots. However, until now the expression of NRT1.2 has been analyzed mainly in roots or shoots, so the analyses provided in this work bring rather novel findings regarding NRT1.2-like proteins' function in other plant tissues. None of the three CsNRT1.2s was significantly expressed in roots when compared with other organs, and only two, CsNRT1.2B and CsNRT1.2C, were clearly transcribed in stem, predominantly under $\mathrm{N}$ deprivation (Fig. 3). Hence cucumber NRT1.2-like proteins may not be involved in nitrate uptake from the soil solution. The expression of CSNRT1.2s was virtually predominant in stem $(N R T 1.2 A)$, cotyledons and old leaves $(N R T 1.2 A / B / C)$ or young petioles $(N R T 1.2 B)$. Nitrogen deficiency or shortage generally enhanced CsNRT1.2C transcription whereas CsNRT1.2B was unaffected (root, stem, old petioles) or stimulated (cotyledons, young petioles) by low nitrate (Fig. 3). Although CsNRT1.2A transcript increased considerably in response to $10 \mathrm{mM} \mathrm{KNO}_{3}$, high nitrate down-regulated CsNRT1.2B and CsNRT1.2C (Fig. 3). Hence, the transporters encoded by genes may be involved in different physiological functions.

CsNRT1.3 was constitutively expressed in all tissues, except for the cotyledons, where the transcript was the most abundant (among vegetative tissues) and significantly enhanced under temporary nitrate provision, high nitrate and, to a lesser extent, low nitrate (Figs. 3 and 4). The functional role of its Arabidopsis homolog still remains unclear, though its expression in roots was repressed by low nitrate and induced by $\mathrm{NO}_{3}{ }^{-}$deprivation (Okamoto et al. 2003). In contrast, AtNRT1.3 expression in shoots was induced by low nitrate treatment (Okamoto et al. 2003). Thus NRT1.3 appears to be nitrate-inducible (cotyledons) or nitrate-constitutive (other tissues). Perhaps NRT1.3 protein participates in nitrate storage within cotyledons under high or low nitrate supply. In addition, the protein seems to be essential for the proper function of reproductive parts, since it is predominantly expressed in flowers (Fig. 2).

In contrast, AtNRT1.4 is expressed predominantly in the leaf petiole, where it is probably involved in nitrate storage (Chiu et al. 2004). In addition, the AtNRT1.4 mRNA was also shown to be constitutively synthesized in roots and nitrate-induced in shoots (Okamoto et al. 2003). Nevertheless, in roots the AtNRT1.4 transcript was significantly more abundant than in shoots (Okamoto et al. 2003). Of the two cucumber NRT1.4s, CsNRT1.4A revealed an AtNRT1.4-like expression pattern, since it was expressed primarily in old and young petioles (Fig. 3). Surprisingly, CsNRT1.4A was induced by nitrate deprivation or low nitrate (Fig. 3) suggesting that the encoded transporter may not be responsible for $\mathrm{NO}_{3}{ }^{-}$accumulation. Contrary to CSNRT1.4A, CsNRT1.4B mRNA was strongly elevated upon high nitrate in cotyledons, old petioles or old leaves (putative storage organs) (Fig. 3). In addition, CsNRT1.4B expression considerably increased upon temporary nitrate provision following $\mathrm{N}$ deprivation, confirming that CsNRT1.4B rather than CsNRT1.4A is a putative functional homolog of AtNRT1.4.

Both AtNRT1.5 and AtNRT1.8 were shown to be involved in long-distance transport of $\mathrm{NO}_{3}{ }^{-}$. AtNRT1.5 appears to mediate nitrate efflux out of root cells and loading into the xylem for transport to the shoot (Lin et al. 2008), whereas AtNRT1.8 is involved in retrieving $\mathrm{NO}_{3}{ }^{-}$from the xylem parenchyma in the roots and shoots ( $\mathrm{Li}$ et al. 2010). Hence, both proteins cooperate to regulate long-distance nitrate transport. All Arabidopsis and cucumber NRT1.5 and NRT1.8 proteins are closely related, since they cluster together and branch off from the main phylogenetic tree (Fig. 1). However, two cucumber proteins CsNRT1.5B and CsNRT1.5C appear to be highly specific for flowers (Fig. 2). In contrast, CsNRT1.5A and CsNRT1.8 were clearly expressed in all organs. Under high nitrate CsNRT1.8 was expressed at the highest level when compared to other CsNRT1s, whereas the CSNRT1.5A transcript was much less abundant and elevated upon $\mathrm{N}$ deprivation (roots, stem, young petioles), low and high nitrate (cotyledons) or high nitrate (old leaves) (Fig. 3). Hence, similarly to CsNRT1.4B CsNRT1.8 is activated upon high external $\mathrm{NO}_{3}{ }^{-}$level. CsNRT1.5A function seems to be more complex and related to some adaptive response of plants to a variable external nitrate supply. In Arabidopsis NRT1.8 was shown to play a significant role in cadmium tolerance leading to nitrate retention in roots to enhance root nitrate assimilation under heavy metal stress (Li et al. 2010). Hence, it was suggested that the coordinated regulation of NRT1.5 and NRT1.8 expression resulting in a reduction of nitrate translocation to shoots could be a common adaptive response of plant to a wide range of stresses (Li et al. 2010; Gojon and Gaymard 2010).

The very recent study on AtNRT1.9 reveals that the last functionally analyzed NRT1 transporter may be 


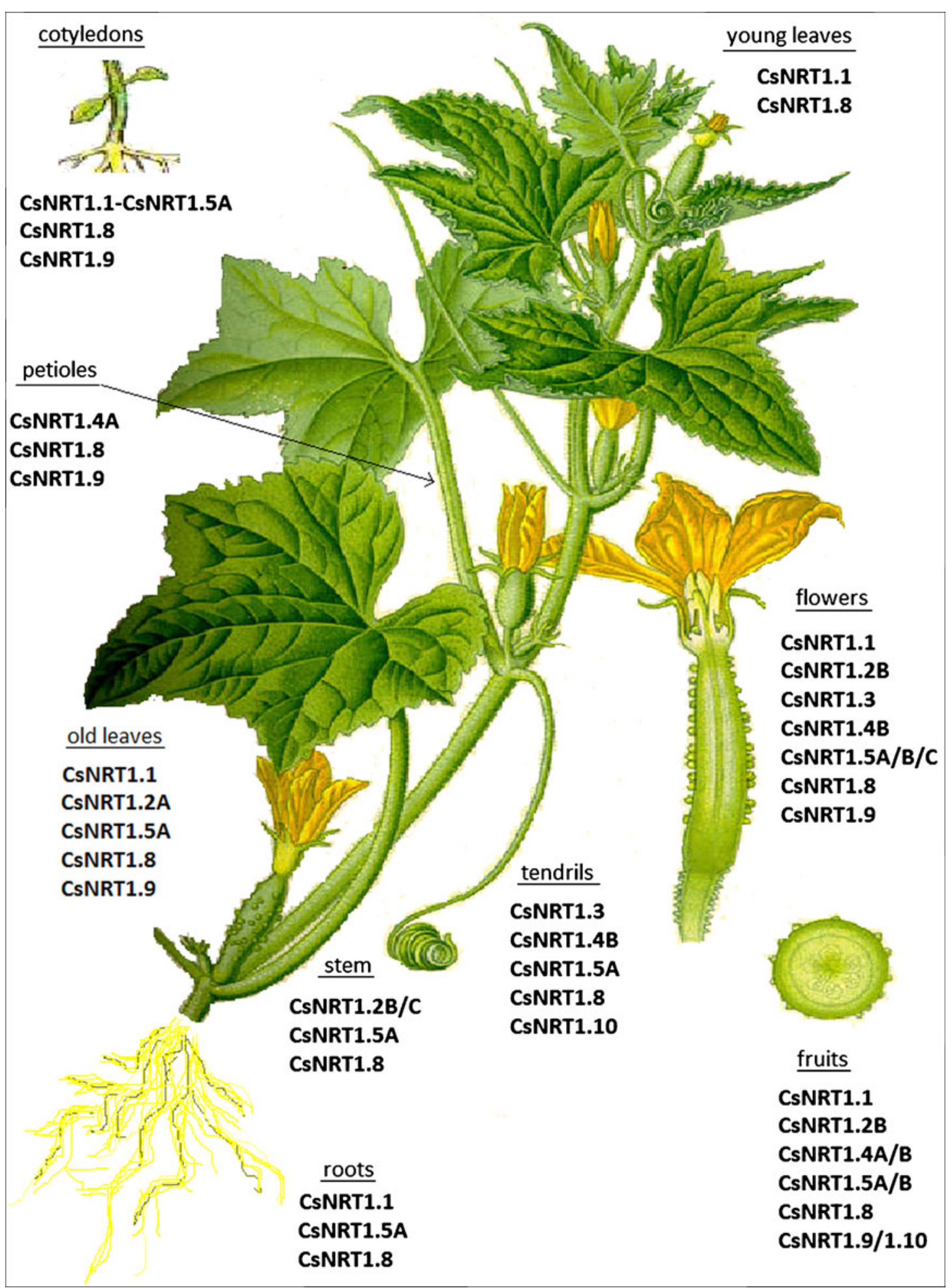

Fig. 5 The whole-plant expression of CSNRT1 genes in cucumber. The picture was created based on the organ expression profile of cucumber genes as well as on the transcription profiles of CSNRT1s under different nitrate availability. Only the genes with the most prominent expression values were included in the picture. To provide an illustration of cucumber plant, a picture of cucumber from Thomé (1885) was modified and adapted for the purposes of this work 
responsible for loading of nitrate into the root phloem to enhance downward nitrate transport in roots (Wang and Tsay 2011). The protein localizes to the plasma membrane and is predominantly expressed in roots (Wang and Tsay 2011). In contrast, the transcript of cucumber homolog is virtually undetectable in the roots of 1-week-, 4week- or even 8-week-old cucumbers, but highly abundant in old leaves and cotyledons (Figs. 2, 3 and 4). In addition, CsNRT1.9 is strongly induced by high nitrate or temporary low nitrate provision (Figs. 3 and 4), suggesting that the encoded protein fulfills different physiological function from its Arabidopsis homolog.

In conclusion, the comparison of the Arabidopsis and cucumber NRT gene families, similarly to the previous comparison of NRT1s in Arabidopsis, poplar and grasses, reveals some striking differences in genes' structure and quantity. Furthermore, expression analyses of CsNRT1s in different cucumber organs under variable nitrate supply suggest that some of the cucumber NRTs are probable functional homologs of their Arabidopsis counterparts (CsNRT1.1, CsNRT1.3, CsNRT1.4B, CsNRT1.5A and CsNRT1.8), whereas other members of this family appear to play distinct physiological roles (CsNRT1.9, CsNRT1.2s, CsNRT1.4A, CsNRT1.5B, CsNRT1.5C). The results presenting the whole picture of CsNRT1s expression in cucumber suggesting the localization of the proteins encoded by genes within plant body are summarized in Fig. 5. All the presented results reveal that we cannot simply predict protein function based on the research on Arabidopsis thaliana and that molecular studies on genes and proteins involved in nitrate uptake and distribution in other species are of high importance to gain a full view of plant responses and adaptations to fluctuating nitrogen status in the soil.

Acknowledgments Wroclaw University (grant no. 2357/W/ IBR/10) and the polish National Science Centre (grant no. N N303 818740) partially supported this work.

Open Access This article is distributed under the terms of the Creative Commons Attribution License which permits any use, distribution, and reproduction in any medium, provided the original author(s) and the source are credited.

\section{References}

Almagro A, Lin HS, Tsay YF (2008) Characterization of the Arabidopsis nitrate transporter NRT1.6 reveals a role of nitrate in early embryo development. Plant Cell 20:32893299
Blumwald E, Poole RJ (1985) $\mathrm{Na}^{+} / \mathrm{H}^{+}$antiport in isolated tonoplast vesicles from storage tissue of Beta vulgaris. Plant Physiol 78:163-167

Chiu CC, Lin CS, Hsia AP, Su RC, Lin HL, Tsay YF (2004) Mutation of a nitrate transporter, AtNRT1:4, results in a reduced petiole nitrate content and altered leaf development. Plant Cell Physiol 45:1139-1148

Chopin F, Orsel M, Dorbe M-F, Chardon F, Truong H-N et al (2007) The Arabidopsis ATNRT2.7 nitrate transporter controls nitrate content in seeds. Plant Cell 19(5):1590-1602

De Angeli A, Monachello D, Ephritikhine G, Frachisse JM, Thomine S, Gambale F, Barbier-Brygoo H (2006) The nitrate/proton antiporter AtCLCa mediates nitrate accumulation in plant vacuoles. Nature 442:939-942

De Angeli A, Monachello D, Ephritikhine G, Frachisse JM, Gambale F, Barbier-Brygoo H (2009) CLC-mediated anion transport in plant cells. Phil Trans R Soc A 364:195-201

Fan S-C, Lin C-S, Hsu P-K, Lin S-H, Tsay Y-F (2009) The Arabidopsis nitrate transporter NRT1.7, expressed in phlo$\mathrm{em}$, is responsible for source-to-sink remobilization of nitrate. Plant Cell 21(9):2750-2761

Filleur S, Daniel-Vedele F (1999) Expression analysis of a highaffinity nitrate transporter isolated from Arabidopsis thaliana by differential display. Planta 207:461-469

Forde BG (2002) Local and long-range signaling pathways regulating plant responses to nitrate. Annu Rev Plant Biol 53:203-222

Geelen D, Lurin C, Bouchez D, Frachisse JM, Lelièvre F, Courtial B, Barbier-Brygoo H, Maurel C (2000) Disruption of putative anion channel gene AtCLC-a in Arabidopsis suggests a role in the regulation of nitrate content. Plant J 21:259-267

Glass ADM, Siddiqi MY (1995) Nitrogen absorption by plant roots. In: Srivastava HS, Singh RP (eds) Nitrogen nutrition in higher plants. Associated Publishing Co, New Delhi, India, pp 21-56

Glass ADM, Britto DT, Kaiser BN, Kronzucker HJ, Kumar A, Okamoto M, Rawat SR, Siddiqi MY, Silim SM, Vidmar JJ, Zhuo D (2001) Nitrogen transport in plants, with an emphasis on the regulation of fluxes to match plant demand. $\mathrm{J}$ Plant Nutr Soil Sci 164:199-207

Glass A, Britto D, Brent G, Kaiser N, Kinghorn J, Kronzucker H, Kumar A, Okamoto M, Rawat S, Siddiqunkle S, Vidmar $\mathrm{J}$ (2002) The regulation of nitrate and ammonium transport systems in plants. J Exp Bot 53(370):855-864

Gojon A, Gaymard F (2010) Keeping nitrate in the roots: an unexpected requirement for cadmium tolerance in plants. $\mathrm{J}$ Mol Cell Biol 6:299-301

Gojon A, Nacry P, Davidian JC (2009) Root uptake regulation: a central process for NPS homeostasis in plants. Curr Opin Plant Biol 12:328-338

Harada H, Kuromori T, Hirayama T, Shinozaki K, Leigh RA (2004) Quantitative trait loci analysis of nitrate storage in Arabidopsis leading to an investigation of the contribution of the anion channel gene, AtCLC-c, to variation in nitrate levels. J Exp Bot 55(405):2005-2014

Ho CH, Lin SH, Hu HC, Tsay YF (2009) CHL1 functions as a nitrate sensor in plants. Cell 138(6):1184-1194

Huang NC, Liu KH, Lo HJ, Tsay YF (1999) Cloning and functional characterization of an Arabidopsis nitrate transporter gene that encodes a constitutive component of lowaffinity uptake. Plant Cell 11:1381-1392 
Huang S, Li R, Zhang Z, Li L, Gu X et al (2009) The genome of the cucumber, Cucumis sativus L. Nat Genet 41:1275-1281

Kabała K, Kłobus G, Janicka-Russak M (2003) Nitrate transport across the tonoplast of Cucumis sativus L root cells. J Plant Physiol 160:523-530

Krouk G, Lacombe B, Bielach A, Perrine-Walker F, Malinska K, Mounier E, Hoyerova K, Tillard P, Leon S, Ljung K, Zazimalova E, Benkova E, Nacry P, Gojon A (2010) Developmental cell nitrate-regulated auxin transport by NRT1.1 defines a mechanism for nutrient sensing in plants. Plant Cell 18(6):927-937

Lejay L, Tillard P, Lepetit M, Olive F, Filleur S, Daniel-Vedele F, Gojon A (1999) Molecular and functional regulation of two uptake systems by $\mathrm{N}$ - and C-status of Arabidopsis plants. Plant J 18:509-519

Li W, Wang Y, Okamoto M, Crawford NM, Siddiqi MY et al (2007) Dissection of the AtNRT2.1:AtNRT2.2 inducible high-affinity nitrate transporter gene cluster. Plant Physiol 143(1):425-433

Li JY, Fu YL, Pike SM, Bao J, Tian W, Zhang Y, Chen CZ, Zhang Y, Li HM, Huang J, Li LG, Schroeder JI, Gassmann WI, Gong JM (2010) The Arabidopsis nitrate transporter NRT1.8 functions in nitrate removal from the xylem sap and mediates cadmium tolerance. Plant Cell 22(5):1633-1646

Lin SH, Kuo HF, Canivenc G, Lin CS, Lepetit M, Hsu PK, Tillard P, Lin HL, Wang YY, Tsai CB, Gojon A, Tsay YF (2008) Mutation of the Arabidopsis NRT1.5 nitrate transporter causes defective root-to-shoot nitrate transport. Plant Cell 20:2514-2625

Liu KH, Tsay YF (2003) Switching between the two action modes of the dual-affinity nitrate transporter CHL1 by phosphorylation. EMBO J 22:1005-1013

Liu KH, Huang CY, Tsay YF (1999) CHL1 is a dual-affinity nitrate transporter of Arabidopsis involved in multiple phases of nitrate uptake. Plant Cell 11:865-874

Migocka M, Papierniak A (2011) Identification of suitable reference genes for studying gene expression in cucumber plants subjected to abiotic stress and growth regulators. Mol Breed 28(3):343-357

Okamoto M, Vidmar J, Glass A (2003) Regulation of NRT1 and NRT2 gene families of Arabidopsis thaliana: responses to nitrate provision. Plant Cell Physiol 44(3):304-317

Orsel M, Filleur S, Fraisier V, Daniel-Vedele F (2002) Nitrate transport in plants: which gene and which control. J Exp Bot 53(370):825-833

Orsel M, Chopin F, Leleu O, Smith SJ, Krapp A et al (2006) Characterization of a two-component high-affinity nitrate uptake system in Arabidopsis. Physiology and proteinprotein interaction. Plant Physiol 142(3):1304-1317

Plett D, Toubia J, Garnett T, Tester M, Kaiser BN, Baumann U (2010) Dichotomy in the NRT gene families of dicots and grass species. PLoS One 5(12):15289

Schumaker KS, Sze H (1987) Decrease of $\mathrm{pH}$ gradients in tonoplast vesicles by $\mathrm{NO}(3)$ and $\mathrm{Cl}$ : evidence for $\mathrm{H}$ - coupled anion transport. The regulation of nitrate and ammonium transport systems in plants. Plant Physiol 83:490496

Segonzac C, Boyer JC, Ipotesi E, Szponarski W, Tillard P, Touraine B, Sommerer N, Rossignol M, Gibrat R (2007) Nitrate efflux at the root plasma membrane: identification of an Arabidopsis excretion transporter. Plant Cell 19 (11):3760-3777

Tamura K, Peterson D, Peterson N, Stecher G, Nei M, Kumar S (2011) MEGA5: molecular evolutionary genetics analysis using maximum likelihood, evolutionary distance, and maximum parsimony methods. Mol Biol Evol. doi:10.1093/mol $\mathrm{bev} / \mathrm{msr} 121$

Thomé W (1885) Flora von Deutschland, Österreich und der Schweiz. http://caliban.mpiz-koeln.mpg.de/thome/band4/ tafel 089.html

Tischner $\bar{R}$ (2000) Nitrate uptake and reduction in higher and lower plants. Plant Cell Environ 2:1005-1024

Touraine B, Gojon A (2001) Integration of nitrate uptake in the whole plant. In: Morot-Gaudry JF (ed) Nitrogen assimilation by plants - physiological, biochemical and molecular aspects. Science Publishers, Enfield (NH, USA)-Plymouth (UK), pp 95-114

Tsay YF, Schroeder JI, Feldmann KA, Crawford NM (1993) The herbicide sensitivity gene CHL1 of Arabidopsis encodes a nitrate-inducible nitrate transporter. Cell 72:705-713

Tsay YF, Almagro A, Chiu CC (2005) A new peptide transporter with a role in seed development. Poster at a Conference of American Society of Plant Biologists, 16-20 July, Seattle, Washington, USA

Tsay YF, Chiu CC, Tsai CB, Ho CH, Hsu PK (2007) Nitrate transporters and peptide transporters. FEBS Lett 581:2290-2300

Von der Fecht-Bartenbach J, Bogner M, Dynowski M, Ludewig $\mathrm{U}$ (2010) CLC-b-mediated $\mathrm{NO}^{-3} / \mathrm{H}^{+}$exchange across the tonoplast of Arabidopsis vacuoles. Plant Cell Physiol 51 (6):960-968

Wang YY, Tsay YF (2011) Arabidopsis nitrate transporter NRT1.9 is important in phloem nitrate transport. Plant Cell 23(5):1945-1957

Wang R, Liu D, Crawford NM (1998) The Arabidopsis CHL1 protein plays a major role in high affinity nitrate uptake. Proc Natl Acad Sci 95:15134-15139

Wirth J, Chopin F, Santoni Vr, Viennois Gl, Tillard P et al (2007) Regulation of root nitrate uptake at the NRT2.1 protein level in Arabidopsis thaliana. J Biol Chem 282 (32):23541-23552

Wóycicki R, Witkowicz J, Gawronski P, Dabrowska J, Lomsadze A et al (2011) The genome sequence of the north-european cucumber (Cucumis sativus L.) unravels evolutionary adaptation mechanisms in plants. PLoS ONE 6(7):22728

Zhao FJ, Wood AP, McGrath SP (1999) Effects of sulphur nutrition on growth and nitrogen fixation of pea (Pisum sativum L.). Plant Soil 212:209-219 